\title{
Rafae Marek
}

\section{Ustanie bytu prawnego spółki kapitałowej a wygaśnięcie jej długów}

Rozwiązanie spółki kapitałowej jako takie ma miejsce po przeprowadzeniu likwidacji i wykreśleniu z rejestru. Prawo dozwala na wykreślenie z rejestru spółki, której cały majątek spieniężono, a mimo to nie zaspokojono wszystkich wierzycieli ${ }^{1}$.

W doktrynie panuje pogląd, że wykreślenie spółki z rejestru nie konwaliduje nieprawidłowości przy jej likwidacji. Zwłaszcza jeśli po wykreśleniu okaże się, że wciąż istnieje majątek spółki, to według tej opinii należy zgodnie z art. 12 ustawy z dnia 20 sierpnia 1997 r. o Krajowym Rejestrze Sądowym² wpis wykreślić i ustanowić dalszą likwidację lub powołać kuratora. Dominuje jednak zdanie, że ze względu na konstytutywny charakter wykreślenia dowiedzenie się o majątku czy zobowiązaniach spółki wykreślonej nie skutkuje dalszym istnieniem spółki w likwidacji. Możliwe jest jedynie powołanie kuratora majątku. Co do sum i przedmiotów złożonych do depozytu sądowego postępowania mogą toczyć się z udziałem osób, którym przedmioty owe powinny przypaść na wypadek nieprzejęcia ich przez wierzycieli zlikwidowanej spółki³

Wykreślenie spółki kapitałowej z rejestru ma charakter konstytutywny, następuje wtedy rozwiązanie spółki sensu stricto, co powoduje ustanie jej bytu prawnego jako osoby prawnej. Trzeba zauważyć, że pod rządami Kodeksu handlowego doktryna przyjmowa-

1 Cf. postanowienie SN z dnia 8 stycznia 2002 r., I CKN 752/99, OSNC 2002, nr 10, poz. 130; postanowienie SN z dnia 18 grudnia 1996 r., I CKN 20/96, OSNC 1997, nr 5 poz. 53. Punktem wyjścia dla niniejszego opracowania był nurt orzeczniczy opracowany przez Ł. Orzechowskiego w „Biuletynie Orzecznictwa Lexis.pl”, www.biuletynorzecznictwa.pl [dostęp: 1.01.2015].

2 Dz.U. 1997 nr 121 poz. 769.

3 A. Rachwał, [w:] System prawa handlowego, t. 2A, red. W. Górecki, S. Włodyka, Warszawa 2007, s. 1046-1047.

4 W. Popiołek, [w:] System prawa handlowego, t. 2B, red. J. Frąckowiak, S. Włodyka, Warszawa 2007, s. 576 i n.; uchwała 7 sędziów SN z dnia 15 marca 1991 r., III CZP 13/91, OSNC 1991, nr 7, poz. 77; postanowienie SN z dnia 19 czerwca 2001 r., CZ 73/01, OSNC 2002, nr 3, poz. 35. 
ła, iż wykreślenie spółki z rejestru nie powoduje utraty jej bytu prawnego tak długo, jak długo istnieje majątek wykreślonej spółki ${ }^{5}$.

W prawie niemieckim, odmiennie niż obecnie w prawie polskim, przyjmuje się, że byt prawny spółki ustaje dopiero w momencie kumulatywnego spełnienia dwóch przesłanek: wykreślenia z rejestru i zupełnego braku majątku (Doppeltatbestand) ${ }^{6}$. We wspólczesnej literaturze polskiej pogląd podobny do niemieckiego Doppeltatbestand, że spółka istnieje, dopóki ma majątek, był wyrażany pod rządami k.h. w okresie II RP. Obecnie nie jest szerzej rozpowszechniony?

Wykreślenie spółki kapitałowej z rejestru tworzy novum prawne, w którym spółka definitywnie traci osobowość prawną. Jednak wykreślenie nie powoduje, zdaniem części orzecznictwa, ostatecznego wygaśnięcia wszystkich jej zobowiązań - wierzytelności mogą być dochodzone od poręczycieli czy innych odpowiedzialnych za długi spółki ${ }^{8}$. Kwestia ta będzie przedmiotem dalszej analizy.

Postępowanie likwidacyjne jako takie nie musi prowadzić do zamknięcia wszystkich spraw spółki, ponieważ zakończenie likwidacji nie wyklucza istnienia długów podmiotu zlikwidowanego. Dopuszczenie wykreślenia spółki mimo długów jest argumentem za odrzuceniem stanowiska zakładającego wygaśnięcie długów spółki z powodu wykreślenia z rejestru9 . Skłania to również do odrzucenia tezy o bezpośredniej sukcesji wspólników w przypadku ujawnienia majątku spółki po jej wykreśleniu ${ }^{10}$. Zlikwidowana spółka

5 Cf. R. Potrzeszcz, Wykreślenie spótki kapitatowej bez (wtaściwej) likwidacji - ze stanowiska wierzycieli, „Rejent”1998, nr 5, s. 142-168. Czy ta koncepcja daje sie pogodzić z obecnym prawem pozytywnym? Zdecydowanie zaprzecza temu np. A. Koniewicz, Majątek polikwidacyjny spótek kapitatowych, „Glosa” 2010, nr 4, s. 42.

6 Cf. K. Schmidt, Gesellschaftsrecht, Köln - Berlin - Bonn - München 2002, s. 316-317, 932, 1203-1204, cit. per: R. Kos, M. Porzycki, Sytuacja prawna majątku pozostatego po wykreśleniu spótki kapitatowej - uwagi na gruncie postulatu przymusowej likwidacji niewyptacalnych spótek, „Monitor Prawa Handlowego” 2013, nr 3, s. 16 i n.

7 R. Potrzeszcz, op. cit., s. 148-152; Cf. pogląd o dalszym istnieniu spółki mimo jej wadliwego wykreślenia: J.P. Naworski, [w:] KSH. Komentarz, red. T. Siemiątkowski, R. Potrzeszcz, t. 2, Warszawa 2011, s. 596-597, teza 12 do art. 272; P. Bielski, Glosa do wyroku SN z 28.10.2005 r. (II CK. 275/05), OSP 2006, nr 11, poz. 126.

8 Cf. M. Michalski, [w:] System prawa prywatnego, t. 17B, red. S. Sołtysiński, Warszawa 2010, s. 902 z powołaniem się na wyrok SA w Warszawie z dnia 6 kwietnia 2006 r., I Aca 1116/05, OSA 2008, nr 1, poz. 10.

9 Postanowienie SN z dnia 10 maja 2012 r., IV CSK 369/11, niepubl.; wyrok SN z dnia 5 listopada 2008 r., I CSK 204/08, niepubl.

10 S. Babiarz, W. Łukowski, Glosa do uchrwaty SN z 24.01.2007 r., III CZP 143/06, „Prawo Spółek” 2010, nr 3. Jeszcze pod rządami Kodeksu handlowego SN wypowiedział się, że nieobjęty likwidacją majątek spółki z o.o. a ujawniony po jej zakończeniu staje się własnością jej byłych wspólników (orzeczenie SN z 26.05.1936 r., C II 331-36, Zbiór Urzędowy 1937, nr 1, poz. 39). Takie stanowisko akceptuje część współczesnej doktryny, np. J. Grykiel, Glosa do uchwaty SN z dnia 24 stycznia 2007 r. (III CZP 143/06), „Glosa” 2011, nr 2, s. 17; A. Januchowski, G. Bart- 
nie ma następcy prawnego, toteż pojawia się podstawa umorzenia postępowania, w którym wierzyciel dochodził roszczeń przeciwko spółce na podstawie 182 k.p.c. Ponadto zgodnie $z$ art. 818 k.p.c. organ egzekucyjny zawiesza postępowanie i stosuje art. $824 \S 2$ k.p.c., wyznaczając termin usunięcia braku. W razie likwidacji spółki i uprawomocnienia się postanowienia o jej wykreśleniu z KRS jasne jest, że brak zdolności sądowej nie może być uzupełniony. Spółka nie ma też sukcesora prawnego, wobec czego celowe staje się umorzenie egzekucji bez wyznaczania terminu na uzupełnienie braku zdolności sądowej ${ }^{11}$. Nie oznacza to jednak wygaśnięcia długów zlikwidowanej spółki.

A. Koniewicz, rozważając powiązaną z problematyką niniejszego artykułu kwestię mienia pozostałego po likwidacji spółek ${ }^{12}$, bierze pod uwagę kilka konstrukcji. Odrzuca teorię następstwa prawnego wspólników ${ }^{13}$ oraz teorię majątku podmiotowego lub bezpodmiotowego, skłania się zaś ku koncepcji prawa podmiotowego przeszłego, co aprobuje Ł. Węgrzynowski ${ }^{14}$. Konstrukcją praw podmiotowych przeszłych posługiwał się S. Grzybowski ${ }^{15}$, zaznaczając że ich wyróżnienie jest potrzebne, gdyż umożliwia unormowanie niektórych rzadkich sytuacji. Prawami przeszłymi można, choć w wąskim zakresie, rozporządzać, zrzekać sie ich czy je zabezpieczać ${ }^{16}$.

Moim zdaniem trafniejsze jest jednak przyjęcie koncepcji praw wtórnie ubezpodmiotowionych ${ }^{17}$, bowiem w przypadku likwidacji i wykreślenia spółki nie mamy do czynienia z sytuacjami podobnymi do uchylania uchwał o podziale czy połączeniu albo do uchylenia postanowienia o uznaniu za zmarłego. Podmiot definitywnie przestał istnieć, wobec

kowiak, Dokonanie likwidacji spótki wykreślonej z rejestru. Glosa do uchwaty Sądu Najwyższego z 24 stycznia 2007 (III CZP 143/06), „Prawo Bankowe”2008, nr 4, s. 33.

11 F. Zedler, Dochodzenie roszczeń wierzycieli handlowej spótki kapitatowej po zakończeniu postępowania upadtościowego obejmującego likwidacje jej majątku, [w:] Problemy polskiego i europejskiego prawa prywatnego. Księga pamiątkowa Profesora Mariana Kępińskiego, red. K. Klafkowska-Waśniowska, M. Mataczyński, R. Sikorski, Warszawa 2012, s. 131 i n.

12 A.Koniewicz,Majątek polikwidacyjnyosób prawnychnaprzyktadziespótek kapitatowych, Warszawa 2010, s. 165-175, cit.per: .. Węgrzynowski, Charakterystyka praw i obowiqzków spótki kapitatowej po jej wykreśleniu z rejestru przedsiębiorców (cz. II), „Przegląd Prawa Handlowego”2014, nr 8, s. 9.

13 Takie stanowisko aprobuje Ł. Węgrzynowski, op. cit., s. 9.

14 Ibidem.

15 System prawa cywilnego, t. I, Część ogólna, red. S. Grzybowski, Wrocław 1974, s. 226-227.

16 A. Koniewicz zwraca uwagę również na inne przypadki „odżycia” prawa podmiotowego - nieuwzględnienie upływu terminu prekluzyjnego, wystąpienie z żądaniem $\mathrm{z}$ art. 60 § 3 k.r.o. po upływie terminu tam zawartego, uchylenie postanowienia o uznaniu za zmarłego, uchylenie uchwały od połączeniu czy podziale spółki, podważenie uchwał podejmowanych w postępowaniu likwidacyjnym, zastosowanie przepisów o wadach oświadczenia woli, konwalidacja na podstawie 63 k.c., przywrócenie członkostwa w spółdzielni. Cf. A. Koniewicz, op. cit., s. 170-174.

17 Cf. o prawach bezpodmiotowych: S. Grzybowski, [w:] Encyklopedia podręczna prawa prywatnego, red. F.Zoll, J. Wasilkowski, t. 3, Warszawa 1939, s. 1475. W Systemie prawa cywilnego (t. I, red. W. Czachórski, Wrocław 1974, s. 454-455) S. Grzybowski już o takich prawach nie wspomniał. 
tego po stronie dłużnika w węźle zobowiązaniowym pozostało „puste miejsce”. Istnieje zaś nadal drugi podmiot - wierzyciel oraz sama wierzytelnośćc ${ }^{18}$.

\section{Stanowisko na rzecz wygaśnięcia długów ze względu na ich związek z osobą dłużnika}

W wyroku z 5 listopada 2008 r. (I CSK 204/08 ${ }^{19}$ ) Sąd Najwyższy przyjął, że skoro wierzytelność to określona sytuacja prawna wobec oznaczonego dłużnika, a dług to określona powinność zachowania się dłużnika wobec wierzyciela, nie może nadal istnieć zobowiązanie w sytuacji utraty bytu prawnego przez jedną ze stron (Sąd nie użył podziału na strony i podmioty stosunku zobowiązaniowego) zobowiązania i braku następstwa prawnego tej strony. Sąd Najwyższy przyznał, że nie stanowi o tym explicite żaden obowiązujący przepis, zaś skutek taki ma wynikać $\mathrm{z}$ istoty stosunku prawnego określonego $\mathrm{w}$ art. $353 \S 1$ k.c. Ponadto urzeczywistnienie poszczególnych uprawnień wierzyciela jest zgodnie z uzasadnieniem orzeczenia o sygn. I CSK 204/08 niemożliwe, jeżeli dłużnik utraci byt prawny. Brak ponadto instytucji materialnoprawnych czy procesowych umożliwiających - w wypadku utraty bytu prawnego przez osobę prawną - realizację uprawnień wierzyciela ${ }^{20}$. Jednak czy brak możliwości realizacji interesu wierzyciela, zresztą jedynie względem byłej spółki, oznacza zarazem wygaśnięcie zobowiązania? Czy Sąd Najwyższy właściwie określił charakter zobowiązania jako więzi inter partes?

Nie budzi wątpliwości, że Kodeks spółek handlowych nie przewiduje sukcesji innych podmiotów w prawa i obowiązki zlikwidowanej spółki kapitałowej wynikające ze stosunków obligacyjnych. Wszczęcie postępowania likwidacyjnego wobec spółki kapitałowej de lege lata nie skutkuje modyfikacją treści stosunków zobowiązaniowych z udziałem tej spółki. Niewykluczone zatem, że z zakończeniem postępowania likwidacyjnego będą kolidować terminy wykonania obowiązków ex contractu przypadające w odleglejszym czasie. Sumy potrzebne do zaspokojenia lub zabezpieczenia znanych spółce wierzycieli, którzy się nie zgłosili lub których wierzytelności nie są wymagalne bądź sporne, składa się do depozytu sądowego, a ważne złożenie do depozytu ma takie skutki praw-

18 Warto w tym miejscu spojrzeć na regulacje ustawy o przejęciu majątku byłej PZPR (Dz.U.1991 nr 16 poz. 72). Jak zasadnie zauważa Ł. Węgrzynowski (op. cit., s. 29-30), art. 1 ust. 2 tej ustawy przyjmuje, że istniejące w dniu wejścia ustawy w życie wierzytelności, środki finansowe i inne prawa majątkowe, poza składkami członkowskimi, przechodzą na własność Skarbu Państwa. Jednak PZPR w dacie wejścia w życie przedmiotowej ustawy już nie istniała, zatem mimo braku bytu prawnego wierzyciela i następstwa prawnego po nim ustawa explicite stwierdzała, że istnieją pozostałe po nim wierzytelności. TK w wyroku z dnia 25 lutego 1992 r. (K 3/91, OTK 1992) uznał, że mamy tu do czynienia z majątkiem bezpodmiotowym.

19 Cf. wyrok SN z dnia 10 lutego 2012 r., II CSK 325/11, o którym aprobująco pisze M. Bączyk, Skutki prawne wadliwego zakończenia postępowania likwidacyjnego spótki z ograniczona odpowiedzialnościq, „Monitor Prawa Bankowego” 2012, nr 11(24), s. 56-59.

20 Cf. uzasadnienie uchwały z 24.01.2007 r., III CZP 143/06, OSNC 2007, nr 11, poz. 166. 
ne, jak spełnienie świadczenia, m.in. wygaśnięcie zobowiązania. Skutek ten następuje ex tunc, z chwilą złożenia sum do depozytu. Gdy likwidowana spółka jest dłużnikiem ze zobowiązania zabezpieczonego poręczeniem, dług powinien być uregulowany albo odpowiednia kwota złożona do depozytu, skutkiem czego wygasa stosunek prawny między wierzycielem i spółką likwidowaną, a w konsekwencji następuje wygaśnięcie zobowiązania poręczyciela. Likwidacja spółki powinna doprowadzić do pełnego wykonania ciążących na spółce obowiązków ze stosunków zobowiązaniowych. Sąd w omawianym orzeczeniu o sygn. I CSK 204/08 zaaprobował tezę, że brak zaspokojenia wierzycieli powinien być przeszkodą w zakończeniu postępowania likwidacyjnego ${ }^{21}$. Pozostaje jednak do rozważenia kwestia zobowiązań, które nie wygasły przez złożenie sum do depozytu.

\section{Stanowisko na rzecz utrzymania się długów mimo ustania bytu prawnego dłużnika}

Jeszcze w wyroku z 6 kwietnia 2006 r. (I ACa 1116/05) stołeczny Sąd Apelacyjny przyjął, że likwidacja i wykreślenie spółki kapitałowej z rejestru nie powoduje wygaśnięcia jej zobowiązań. Mogą być one dochodzone od osób odpowiadających za nie z tytułu udzielonych zabezpieczeń czy poręczeń ${ }^{22}$. Stanowisko takie spotkało się z aprobatą Sądu Najwyższego, który w wyroku z 27 czerwca 2014 r. (V CSK 440/13, LEX nr 15045870), zauważył, że przyjęcie, iż długi spółki kapitałowej wygasają w momencie ustania jej bytu prawnego, skutkuje znaczącym pogorszeniem sytuacji jej wierzycieli, bowiem jest równoznaczne z wygaśnięciem praw akcesoryjnych. Ponadto oznacza - jak podnosi SN w wyroku o sygn. V CSK 440/13 - wprowadzenie zróżnicowania w odniesieniu do statusu osób fizycznych, których długi są dziedziczne, i osób prawnych bez dostatecznego uzasadnienia normatywnego, a także pojawienie się niekorzystnych perspektyw funkcjonowania tych ostatnich w obrocie. Podobnie wypowiedział się Sąd Najwyższy w postanowieniu z 10 maja 2012 r. (IV CSK 369/11, LEX nr 1238133). Zgodnie z tym orzeczeniem wierzytelność, której dłużnikiem jest osoba prawna, nie wygasa w momencie wykreślenia dłużnika z rejestru po zakończenia postępowania upadłościowego, jeżeli charakter tej wierzytelności jest taki, że możliwe jest jej zaspokojenie z substratu ma-

21 Cf. uchwała SN z dnia 26 kwietnia 1995 r., III CZP 44/95, OSNC 1995, nr 9, poz. 123. Jest to postulat zasadny z punktu widzenia dobrych obyczajów kupieckich. Cf. jednak postanowienia SN: z dnia 18 grudnia 1996 r., I CKN 20/96, OSNC 1997, nr 5, poz. 53; z dnia 8 stycznia 2002 r., I CKN 752/99, OSNC 2002, nr 10, poz. 130; z dnia 5 grudnia 2003 r., IV CK 256/02, Lex nr 134088.

22 J. Grykiel, Utrata bytu prawnego przez spótkę z o.o. a jej zobowiq̨ania, „Monitor Prawniczy” 2008, nr 1, s. 49-50 (glosa krytyczna do I Aca 1116/05). Autor ten przyjmuje wygaśnięcie zobowiązań spółki wskutek utraty przez nią bytu prawnego, stwierdzając, że istnieje zasada ścisłego powiązania zobowiązań z podmiotami prawa, co ma wykluczać istnienie zobowiązania bez podmiotu zobowiązanego, zatem aprobuje wyżej przedstawione rozumowanie SN. 
jątkowego pozostałego po osobie prawnej (np.w razie złożenia odpowiednich kwot do depozytu sądowego) czy też z zabezpieczeń tej wierzytelności na przedmiotach majątkowych osób trzecich.

W postanowieniu o sygn. IV CSK 369/1123 Sąd trafnie podkreślił, że żaden przepis nie stanowi o wygaśnięciu wierzytelności w stosunku do dłużnika-osoby prawnej w razie wykreślenia jej z rejestru. Takiego skutku prawnego nie można też wywieść $\mathrm{z}$ analizy przepisów dotyczących likwidacji osoby prawnej. Nie ma lex generalis pozwalającej wskazać, co oznacza pojęcie „wygaśnięcie wierzytelności”. I w orzecznictwie, i w piśmiennictwie przyjmuje się, że do wygaśnięcia wierzytelności dochodzi również na skutek zdarzeń, z którymi żaden przepis nie wiąże wprost wyartykułowanego skutku w postaci wygaśnięcia wierzytelności lub skutku określonego jako „wygaśnięcie zobowiązania” czy „wygaśnięcie długu”.

Sąd Najwyższy w orzeczeniu o sygn. IV CSK 369/11 zasadnie uznał, że zdefiniowanie warunków „wygaśnięcia wierzytelności” w celu oceny, czy obejmuje ono sytuację spowodowaną prawomocnym wykreśleniem $\mathrm{z}$ rejestru dłużnika osobistego, może nastąpić tylko przez próbę uogólnienia przyczyn, które bezspornie skutkują wygaśnięciem wierzytelności. $Z$ pewnością wygaśnięcie wierzytelności nastąpi wówczas, gdy zaspokojony zostanie interes prawny wierzyciela. Jednakże gdy nie dochodzi do zaspokojenia interesu wierzyciela, wygaśnięcie wierzytelności ma miejsce, o ile następuje zniesienie stosunku obligacyjnego, zatem nie można przyjąć dalszego istnienia wierzytelności o dotychczasowej treści. Wedle tegoż postanowienia wygaśnięcie wierzytelności nie zajdzie, gdy brak zaspokojenia interesu wierzyciela określonego treścią zobowiązania jest następstwem jedynie braku możliwości skutecznego przymusowego dochodzenia świadczenia ${ }^{24}$.

Zgodnie $\mathrm{z}$ tezami postanowienia o sygn. IV CSK 369/11 zestawienie tego wniosku $\mathrm{z}$ regulacją postępowań likwidacyjnych osób prawnych potwierdza, że ustawodawca nie utożsamia wygaśnięcia zobowiązania, a wraz z nim wynikających z niego wierzytelności, z ustaniem bytu prawnego dłużnika będącego osobą prawną.

Ponadto owo postanowienie głosi, że ułomnością tezy o wygasaniu wierzytelności wraz z utratą bytu prawnego jednej ze stron zobowiązania ${ }^{25}$ jest to, że skutek w postaci wygaśnięcia wierzytelności jest wyprowadzany tylko z doktrynalnej konstrukcji

23 Ł. Węgrzynowski (op. cit., s. 8-9) zwraca uwagę, że choć orzeczenie zmierza w dobrym kierunku, zwłaszcza jeśli chodzi o skutki prawne złożenia przedmiotu świadczenia do depozytu sądowego, to nie jest jasne, czy odnosi się do każdego przypadku wykreślenia spółki kapitałowej z rejestru, czy tylko do wypadków, gdy w toku likwidacji złożono do depozytu sumy na podstawie art. 285 i 473 k.s.h. Autor zaznacza też, że wątpliwe jest sięgnięcie przez SN do konstrukcji zobowiązania naturalnego.

24 M. Pyziak-Szafnicka, [w:] System prawa prywatnego, t. 6, red. A. Olejniczak, Warszawa 2014, s. 1464-1465, gdzie nie wskazano likwidacji podmiotu jako sposobu wygaśnięcia zobowiązania.

25 Cf. wyroki SN z dnia 7 października 2008 r., III CSK 112/2008 (Lex Polonica nr 1955485) i z dnia 5 listopada 2008 r., I CSK 204/08 (Lex nr 484664) oraz powyższe wywody. 
zobowiązania, zatem nie wynika wprost z obowiązujących przepisów. Stanowisko takie znacznie osłabia ochronę wierzycieli osób prawnych, ponieważ wygaśnięcie wierzytelności w stosunku do tych podmiotów prowadziłoby także do wygaśnięcia praw akcesoryjnych. Należy pamietać, że postępowania likwidacyjne mają na celu nie tylko zaspokojenie wierzycieli likwidowanego, lecz także usunięcie z obrotu podmiotów niezdolnych do dalszego w nim funkcjonowania. Ten praktyczny aspekt stanowił dla Sądu Najwyższego uzasadnienie przyjęcia możliwości wykreślenia likwidowanej osoby prawnej z właściwego rejestru mimo stwierdzenia, że w toku postępowania likwidacyjnego nie doszło do zaspokojenia wszystkich wierzycieli likwidowanej osoby prawnej ${ }^{26}$.

Także w postanowieniu z dnia 27 czerwca 1995 r. (III CRN 28/95, OSNC 1995, nr 11, poz. 165) Sąd Najwyższy przyjął, że niezaspokojenie wierzycieli i niezabezpieczenie ich wierzytelności nie stanowi przeszkody w likwidacji przedsiębiorstwa i wykreślenia go z rejestru jeśli majątek owego przedsiębiorstwa nie wystarcza na zaspokojenie wierzycieli $^{27}$. W postanowieniu tym Sąd podkreślił, że uzależnienie likwidacji przedsiębiorstwa państwowego od zaspokojenia lub zabezpieczenia wierzytelności w razie braku adekwatnego majątku powodowałoby niemożność likwidacji przedsiębiorstwa. Wzgląd na ochronę wierzycieli stałby się przeszkodą dla wykreślenia z rejestru likwidowanych osób prawnych. Zdarzają się również sytuacje, gdy po wykreśleniu z rejestru osoby prawnej wychodzi na jaw, że pozostał po niej majątek. Wobec braku regulacji prawa pozytywnego w uchwale z 24 stycznia 2007 r. (III CZP 143/06, OSNC 2007, nr 11, poz. 166) przyjęto, że jeśli po wykreśleniu z rejestru spółki z o. o. okaże się, że pozostały po niej składniki majątku nieobjęte likwidacją, dozwolone jest ustanowienie likwidatora do dokończenia likwidacji. Wydaje się, że pojawiłaby się wówczas możliwość uregulowania należności niezaspokojonych wierzycieli, co jest jednym celem każdego postępowania likwidacyjnego, jak zwraca uwagę Sąd w orzeczeniu o sygn. IV CSK 369/11.

Również we wcześniejszym niż to postanowienie orzecznictwie panuje pogląd uznający istnienie wierzytelności w oderwaniu od bytu prawnego dłużnika. W postanowieniu z 20 września 2007 r. (II CSK 240/07, Lex nr 487505) Sąd Najwyższy nie zaaprobował tezy, że wykreślenie spółki z o.o. prowadzi do wygaśnięcia jej zobowiązań bez konieczności zaspokojenia wierzycieli. Gdyby zaspokojenie owo traktować jako warunek zakończenia likwidacji, czyli negatywną przesłankę wykreślenia z rejestru, oznaczałoby to utrzymywanie bytu spółki mimo zupełnej utraty zdolności uczestniczenia w działalności gospodarczej przy jednoczesnym braku jakichkolwiek możliwości świadczenia wierzycielom. Sąd Najwyższy w orzeczeniu o sygn. IV CSK 369/11 zwraca uwagę, że w po-

26 Cf. postanowienie SN z dnia 18 grudnia 1996 r., I CKN 20/96, OSNC 1997, nr 5, poz. 53; z dnia 8 stycznia 2002 r., I CKN 752/99, OSNC 2002, nr 10, poz. 130; z dnia 5 grudnia 2003 r., IV CK 256/02, Lex nr 134088.

27 Art. 18a ust. 1 ustawy z dnia 25 września 1981 r. o przedsiębiorstwach państwowych, t.j. Dz.U. 2013 poz. 1384 z późn. zm. 
stanowieniu tym utratę bytu prawnego spółki z o.o. Sąd powiązał z utratą możliwości zaspokojenia wierzycieli, a nie ze zwolnieniem spółki ze zobowiązań.

Sąd w postanowieniu o sygn. IV CSK 369/11 zasadnie stwierdza, że ustawodawca zakłada, przynajmniej implicite, istnienie zobowiązań mimo ustania bytu prawnego dłużnika. Zgodnie $z$ art. 356 ust. 2 Prawa upadłościowego ${ }^{28}$ sumę wydzieloną na zaspokojenie wierzytelności, której zapłata zależy od warunku zawieszającego, wydaje się wierzycielowi, jeżeli udowodni, że warunek się ziścił, w przeciwnym razie sumę składa się do depozytu sądowego. W myśl dawniejszego brzmienia art. 360 Prawa upadłościowego ${ }^{29}$, m.in. po zakończeniu postępowania upadłościowego, sumy zatrzymane w depozycie, o ile nie przypadły osobie wskazanej w planie podziału, wydawano upadłemu na jego wniosek. Ostatnia część przepisu nie odnosiła się do upadłego będącego osobą prawną, który na mocy właściwych przepisów zawartych poza Prawem upadłościowym, zostaje wykreślony z rejestru w następstwie zakończenia postępowania upadłościowego. Jednak - jak zasadnie zauważył Sąd Najwyższy w orzeczeniu o sygn. IV CSK 369/11 - z powyższych przepisów wynika, że i po zakończeniu postępowania upadłościowego wobec osób prawnych - którego skutkiem jest wykreślenie ich z rejestru - prawo nie wyklucza istnienia wierzytelności warunkowych ze stosunków obligacyjnych, których stroną był upadły.

Prawdą jest, że ważne złożenie do depozytu sądowego ma skutki spełnienia świadczenia - prowadzi do wygaśnięcia zobowiązania. Jednak oczekiwanie, również po zakończeniu postępowania upadłościowego (nawet więc po wykreśleniu upadłego z rejestru), na ziszczenie się warunku wskazuje, że skutki prawne wywołuje dotychczasowa treść stosunku zobowiązaniowego łączącego wierzyciela oraz upadłego jako dłużnika, którego elementem jest warunek zawieszający. Podobne unormowania dotyczą postępowań likwidacyjnych spółek kapitałowych. Taką regulacją jest art. 18a ust. 1 ustawy o przedsiębiorstwach państwowych, z którego wynika, że wykreślenie z rejestru przedsiębiorstwa państwowego może być dokonane przed zaspokojeniem jego wierzycieli o ile nastąpi zabezpieczenie. Sąd Najwyższy w postanowieniu o sygn. IV CSK 369/11 zasadnie wywodzi, że wierzytelności te utrzymują się po utracie podmiotowości prawnej przedsiębiorstwa. Także art. 127 ustawy z dnia 16 września 1982 r. Prawo spółdzielcze ${ }^{30}$ zakłada możliwość wykreślenia spółdzielni z KRS w razie złożenia do depozytu sądowego kwot na zabezpieczenie należności niewymagalnych.

Uwzględniając te unormowania oraz biorąc pod uwagę kwestie dotyczące sytuacji, w których dochodzi do wygaśnięcia wierzytelności, Sąd Najwyższy w postanowieniu IV CSK 369/11 jasno stwierdza, że wierzytelność, której dłużnikiem osobistym jest osoba

28 T.j. Dz.U. 2015 poz. 233.

29 Przepis ów zyskał nowe brzmienie z dniem 1 stycznia 2016 r., jednak nie ma to wpływu na problematykę prezentowaną $\mathrm{w}$ niniejszym artykule.

30 T.j. Dz.U. 2016 poz. 21. 
prawna, nie wygasa $z$ chwilą wykreślenia tejże osoby z rejestru na skutek zakończenia postępowania upadłościowego, jeżeli charakter tej wierzytelności umożliwia zaspokojenie jej z substratu majątkowego pozostałego po osobie prawnej lub z zabezpieczeń tej wierzytelności na przedmiotach majątkowych osób trzecich.

W opinii Sądu Najwyższego zawartej w orzeczeniu o sygn. IV CSK 369/11 w wypadku istnienia majątku byłej osoby prawnej lub zabezpieczeń na mieniu osób trzecich likwidacja osoby prawnej prowadzi do powstania sytuacji podobnej w skutkach do zobowiązania naturalnego. Choć konstrukcja prawna zobowiązania wymaga istnienia dłużnika jako podmiotu, który jest zobowiązany do spełnienia określonego świadczenia, to w momencie powstania określonej wierzytelności znaczenie (z perspektywy wierzyciela) ma istnienie substratu majątkowego, z którego wierzytelność może być zaspokojona, oraz kwestia istnienia podmiotu, do którego można skierować roszczenie. Wedle postanowienia o sygn. IV CSK 369/11 w takich wypadkach nie można przyjąć zaistnienia następczej niemożliwości świadczenia (art. 475 k.c.). Utrata bytu prawnego nie niweczy ani nie modyfikuje dotychczasowej treści stosunku zobowiązaniowego, lecz prowadzi do swoistej konserwacji jego treści i niemożności dochodzenia roszczeń przeciwko nieistniejącemu dłużnikowi oraz braku możliwości wykonywania uprawnień prawokształtujących wynikających $\mathrm{z}$ wierzytelności.

Sąd Najwyższy w postanowieniu IV CSK 369/11 zaznacza też, że wygasną jedynie wierzytelności, w których niezbędne jest istnienie dłużnika osobistego. Jeżeli przyjąć odmienny pogląd, potrzeba ochrony praw wierzycieli powodowałby konieczność przyjęcia, że warunkiem sine qua non wykreślenia osoby prawnej jest wcześniejsze wykorzystanie - chociażby w określonym terminie - przez wierzycieli posiadanych zabezpieczeń. $Z$ art. 477 § 1 k.s.h. - dotyczącego rozwiązania spółki akcyjnej po zakończeniu postępowania upadłościowego - oraz z innych przepisów procedury likwidacyjnej osób prawnych nie można wnioskować, że wykreślenie osób prawnych z rejestru zależy od oceny wpływu tego zdarzenia na ochronę praw wierzycieli spółki czy innych osób prawnych. Podobnie - jak zwraca uwagę Sąd Najwyższy w orzeczeniu o sygn. IV CSK 369/11 - ukształtowane orzecznictwo dotyczące warunków wymaganych do wykreślenia osób prawnych w skutek przeprowadzenia postępowań likwidacyjnych nie przywiązuje do tej kwestii wagi, o ile nie istnieje już majątek likwidowanego podmiotu. Również w prawie upadłościowym nie ma przepisów nakazujących uwzględniać przy orzekaniu o zakończeniu postępowania upadłościowego ochronę praw akcesoryjnych wierzycieli upadłego-osoby prawnej.

\section{Wnioski}

Obecnie w nauce polskiej przyjęta jest opinia o zasadności wprowadzenia obok pojęcia podmiotu również pojęcia strony zobowiązania. Uzasadnił ją przede wszystkim Alfred 
Klein ${ }^{31}$. Pojęcie strony może być użyte do opisania konkretnych stosunków zobowiązaniowych, w których tymczasowo brak osoby uprawnionej ${ }^{32}$. Można tu per analogiam mówić o braku podmiotu po stronie dłużnika, gdy utracił on byt prawny (ubezpodmiotowienie), jednak brak podmiotu nie będzie pociągał za sobą wygaśnięcia zobowiązania, podobnie jak wtedy, gdy podmiot jeszcze nie jest dookreślony, a zobowiązanie jednak istnieje. Analogiczne do zindywidualizowania będzie tu moim zdaniem wskazanie na odpowiedzialnego rzeczowo czy poręczyciela, który będzie podstawiony (w sensie nietechnicznym) w miejsce dawnego dłużnika ${ }^{33}$.

Trzeba też zwrócić uwagę, że Sąd Najwyższy w orzeczeniach opowiadających się za wygaśnięciem długów zlikwidowanej spółki zdaje sie przychylać do dawnej zasady ius commune „nomina ossibus inhaerent”. Jednak w rozwoju historycznym utrwalił się pogląd na wierzytelność jako dobro majątkowe i przedmiot obrotu. Stopniowo popadały w zapomnienie koncepcje ścisłego związku wierzytelności z osobą wierzyciela i niemożności przenoszenia jej na inne podmioty ${ }^{34}$. Podobnie odrywał się dług od osoby zobowiązanej. Koncepcja zwalniającego przejęcia długu, opierającego się na następstwie prawnym osoby trzeciej w miejsce dotychczasowego dłużnika, pojawiła się dopiero w XIX wieku. Wcześniej tego rodzaju translatywną zmianę dłużnika wykluczano, opierając się na rzymskim poglądzie o ściśle osobistym charakterze długu i związanej z nim odpowiedzialności. Zmiany podmiotowe łączyły się z naruszeniem tożsamości stosunku zobowiązaniowego, zwykle z wygaśnięciem vinculum iuris ${ }^{35}$. W 1853 r. Berthold Delbrück przedstawił założenia nowej konstrukcji zmiany dłużnika, wyróżniając w ramach stosunku zobowiązaniowego poszczególne składniki, takie jak dług i wierzytelność, ujęte jako res incorporales czy też urzeczowione jako aktywa i pasywa majątku danego podmiotu prawa cywilnego ${ }^{36}$. Wskazał również na możliwości dokonywania poprzez czynność

31 A. Klein, Elementy zobowiazaniowego stosunku prawnego, Wrocław 2005, s. 34 i n. (lub wydania wcześniejsze).

32 Ibidem, s.36; P. Machnikowski, System prawa prywatnego t. 5, red. E. Eętowska, Warszawa 2006, s. 115-116.

33 Cf. rozważania P. Machnikowskiego na temat oznaczenia podmiotów w zobowiązaniu: op. cit., s. 120-123 i 458-461. Wobec tego, że wraz z wykreśleniem spółki z rejestru traci ona podmiotowość prawną, uprawnionymi stają się osoby, którym poszczególne prawa spółki miały przypaść. $\mathrm{Z}$ majątku pozostałego po spółce, którym zajmuje się kurator, mogą zaspokoić się wierzyciele (A. Kidyba, Komentarz aktualizowany do art. $289 \mathrm{KSH}$, teza 2, SIP Lex 2015, tam też dalsza literatura). Ponadto wykreślenie z KRS dłużnika - spółki kapitałowej nie przekreśla ochrony jej wierzycieli na podstawie art. 527 i n. k.c. (cf. uchwała SN z dnia 11 września 2013 r., III CZP 47/13, niepubl.; A. Kidyba, Komentarz do art. $272 \mathrm{KSH}$...).

34 Cf. K. Zawada, Umowa przelewu, Kraków 1990, s. 8 i n.

35 W. Rozwadowski, Przelew wierzytelności w prawie rzymskim, Poznań 1969, s. 157.

36 B. Delbrück, Die Ubernahme fremder Schulden nach gemeinem und preussischem Rechte, Berlin 1853, s. 3. Przeciwko dopuszczalności sukcesyjnego przejęcia długu wypowiadał się F.K. von Savigny, Das obligationenrecht als theil des heutigen römischen rechts, t. II, Berlin 1853, s. 5; idem, 
„przejęcia długu” (Schuldübernahme) przeniesienia wydzielonego długu na inny podmiot bez wygasania zobowiązania ${ }^{37}$.

Wobec niekwestionowanej zasady oderwania długu od osoby dłużnika, która stanowi podbudowę dla dopuszczalności zmiany dłużnika, oraz odróżnienia strony zobowiązania od jego podmiotów trafne jest stanowisko opowiadające się za utrzymaniem się długów podmiotu wykreślonego $\mathrm{z}$ rejestru i to nawet $\mathrm{w}$ sytuacji niepozostawienia przez niego jakichkolwiek aktywów, a jedynie długów. Mamy tu do czynienia z tworem podobnym do hereditas iacens prawa rzymskiego, składającej się wyłącznie z jednego czy większej liczby długów.

Trzeba zaznaczyć, że wprowadzony w 2015 r. art. 25e ustawy o $\mathrm{KRS}^{38}$ potwierdza pogląd o niewygasaniu długów zlikwidowanej osoby prawnej w niektórych wypadkach. Stwierdza bowiem, że Skarb Państwa nabywa nieodpłatnie i ex lege mienie wykreślone z Rejestru w skutek nowo wprowadzonego postępowania ex officio podmiotu oraz że Skarb Państwa ponosi odpowiedzialność z nabytego mienia za zobowiązania podmiotu wykreślonego. Roszczenia wierzycieli natomiast wygasają, jeżeli nie będą dochodzone w ciągu roku od chwili nabycia mienia przez Skarb Państwa. Jeśli zaś przed takim nabyciem mienia wierzyciel uzyskał tytuł egzekucyjny przeciwko podmiotowi wykreślonemu, roszczenie stwierdzone w tymże tytule wygasa, gdy wierzyciel nie wniesie o wszczęcie egzekucji w terminie roku od chwili nabycia mienia przez Skarb Państwa. Widać tu pewne podobieństwa do instytucji dziedzica koniecznego, która pozwala uniknąć istnienia herditates iacentes.

Konkludując, warto spojrzeć na ważną kwestię odpowiedzialności za długi zlikwidowanej spółki członków zarządu i likwidatorów. Art. 299 k.s.h. stanowi o odpowiedzialności członków zarządu za zobowiązania spółki - jest to odpowiedzialność o charakterze subsydiarnym ${ }^{39}$, uwarunkowana niedochowaniem określonych aktów staranności, co skutkowało bezskutecznością egzekucji wobec spółki. Odpowiedzialność na podstawie art. 299 k.s.h. ponoszą poza członkami zarządu likwidatorzy ${ }^{40}$. Utrzymuje się ona po wy-

System des heutigen römischen Rechts, t. III, Berlin 1840, s. 15; A. Thibaut, System des PandektenRechts, t. II, Jena 1803, s. 304-305.

37 Cit. per: P. Drapała, System prawa prywatnego, t. 6, red. A. Olejniczak, Warszawa 2014, s. 13891390, 1424-1426.

38 T.j. Dz. U. 2015, poz. 1142, 1893, 1923.

39 A. Kidyba, Komentarz aktualizowany do art. 299 KSH, teza 1, SIP Lex 2015; I. Weiss, A. Szumański, [w:] W. Pyzioł, A. Szumański, I. Weiss, Prawo spótek, Warszawa 2014, s. 566. Trzeba pamiętać, że art. 299 k.s.h. nie narusza jako lex generalis przepisów ustanawiających odpowiedzialność członków zarządu idącą dalej. Cf. I. Weiss, A. Szumański, [w:] W. Pyzioł et al., op. cit., s. 573-574; wyrok SN z dnia 21 września 2005 r., V CK 129/05, „Monitor Prawniczy” 2005, nr 20.

40 Cf. stanowisko SN w uchwale z dnia 28 lutego 2008 r., III CZP 143/07, LEX nr 346311; w uchwale z dnia 28 stycznia 2010 r., III CZP 91/09, „Biuletyn SN”2010, nr 1, poz. 12; w wyroku z dnia 25 lutego 2010 r., V CSK 248/09, „Biuletyn SN” 2010, nr 5, poz. 13; odmiennie, na 
kreśleniu spółki z rejestru ${ }^{41}$. Odpowiedzialność owa nie obejmuje jednak, co wydaje się bezsporne, członków rady nadzorczej, komisji rewizyjnej itp. a także wspólników, prokurentów i innych osób trzecich ${ }^{42}$. Osoby wymienione w art. 299 § 1 k.s.h. stają się dłużnikami niezaspokojonego wierzyciela (wyrok SN z 18 kwietnia 2007 r., V CSK 55/07, LEX nr 251525), jednak nie można powiedzieć, by stawały się następcami prawnymi spółki, w tym spółki zlikwidowanej. Można tu mówić o oryginalnym polskim odpowiedniku czy też substytucie tzw. przekłucia welonu korporacyjnego ${ }^{43}$.

\section{Literatura}

Babiarz S., Łukowski W., Glosa do uchwaty SN z 24.01.2007 r., III CZP 143/06, „Prawo Spółek” 2010, nr 3.

Bączyk M., Skutki prawne wadliwego zakończenia postępowania likwidacyjnego spótki z ograniczonq odpowiedzialnościa, „Monitor Prawa Bankowego” 2012, nr 11(24).

Bielski P., Glosa do wyroku SN z 28.10.2005 r. (II CK. 275/05), OSP 2006, nr 11, poz. 126.

Delbrück B., Die Übernahme fremder Schulden nach gemeinem und preussischem Rechte, Berlin 1853.

Drapała P., System prawa prywatnego, t. 6, red. A. Olejniczak, Warszawa 2014.

Encyklopedia podręczna prawa prywatnego, red. F. Zoll, J. Wasilkowski, t. 3, Warszawa 1939.

Grykiel J., Utrata bytu prawnego przez spótkę z o.o. a jej zobowiązania, „Monitor Prawniczy” 2008, nr 1.

rzecz braku odpowiedzialności likwidatora na podstawie art. 299 k.s.h.: wyrok SN z dnia 6 lipca 2007 r., III CSK 2/07, OSNC-Zbiór Dodatkowy 2008, nr 3, poz. 63. Stanowisko to znalazło poparcie części doktryny. Cf. A. Kidyba, Komentarz do art. 299 KSH..., teza 2; M. Rodzynkiewicz, Komentarz do art. 299 KSH, SIP Lex-Lexis Nexis 2014, teza 9. K. Osajda (Odpowiedzialnośc cywilna cztonków zarządu za zobowiq̨zania spótki z o.0., SIP Lex 2014, r. VI 2) konkluduje, że pytanie o odpowiedzialność likwidatorów na gruncie art. 299 k.s.h. pozostaje przedmiotem dyskusji.

41 Cf. K. Osajda, op. cit., r. VII 2.1. Spory budzi problem podnoszenia przez członków zarządu zarzutów przysługujących spółce wobec wierzyciela (ibidem). Pojawia się też kwestia dziedziczności długów powstałych wskutek zastosowania art. 299 k.s.h. Zasadne wydaje się przyjęcie, że odpowiedzialność z art. 299 k.s.h. nie ma charakteru ściśle osobistego, wobec tego nie gaśnie wraz ze śmiercią zobowiązanego i wchodzi w skład spadku. Duże znaczenie ma tu moment zaistnienia stanu bezskuteczności egzekucji wobec spółki. Gdy zajdzie to przed śmiercią członka zarządu, dług będzie częścią spadku po nim (ibidem, r. VI 3).

$42 \mathrm{~W}$ ten sposób A. Kidyba, Komentarz do art. 299 KSH..., teza 2; A. Kappes, Odpowiedzialność cztonków zarzadu za zobowiazania spótki z o.o., Kraków - Warszawa 2009, s. 147-148; K. Osajda, Niewyptacalność spótki z o.o.: odpowiedzialność cztonków zarzadu wobec jej wierzycieli, Warszawa 2014, s. 301.

43 I. Weiss, A. Szumański, op. cit., s. 564. O podziale kwoty likwidacyjnej: ibidem, s. 603-604. 
Grykiel J., Glosa do uchwaty SN z dnia 24 stycznia 2007 r. (III CZP 143/06), „Glosa” 2011, nr 2.

Januchowski A., Bartkowiak G., Dokonanie likwidacji spótki wykreślonej z rejestru. Glosa do uchwaty Sądu Najwyższego z 24 stycznia 2007 (III CZP 143/06), „Prawo Bankowe” 2008, nr 4.

Kidyba A., Komentarz aktualizowany do art. 299 KSH, teza 1, SIP Lex 2015.

Klein A., Elementy zobowiazaniowego stosunku prawnego, Wrocław 2005.

Koniewicz A., Majątek polikwidacyjny spótek kapitatowych, „Glosa”2010, nr 4.

Kos R., Porzycki M., Sytuacja prawna majątku pozostatego po wykreśleniu spótki kapitatowej-uwagi na gruncie postulatu przymusowej likwidacji niewyptacalnych spótek, „Monitor Prawa Handlowego" 2013, nr 3.

Kappes A., Odpowiedzialność cztonków zarzqdu za zobowiq̨zania spótki z o.o., Kraków Warszawa 2009.

KSH. Komentarz, red. T. Siemiątkowski, R. Potrzeszcz, Warszawa 2011.

Osajda K., Nierwyptacalnośćspótki z o.o.: odpowiedzialność cztonków zarzadu wobec jej wierzycieli, Warszawa 2014.

Osajda K., Odpowiedzialność cywilna cztonków zarzqdu za zobowiqzania spótki z o.o., SIP Lex 2014, VI 2.

Potrzeszcz R., Wykreślenie spótki kapitatowej bez (wtaściwej) likwidacji - ze stanowiska wierzycieli, „Rejent”1998, nr 5.

Pyzioł W., Szumański A., Weiss I., Prawo spótek, Warszawa 2014.

Rodzynkiewicz M., Komentarz do art. 299 KSH, SIP Lex-Lexis Nexis 2014, teza 9.

Rozwadowski W., Przelew wierzytelności w prawie rzymskim, Poznań 1969.

Savigny F.K. von, Das obligationenrecht als theil des heutigen römischen rechts, t. II, Berlin 1853.

Schmidt K., Gesellschaftsrecht, Köln - Berlin- Bonn - München 2002.

System prawa handlowego, t. 2A, red. W. Górecki, S. Włodyka, t. 2B, red. J. Frąckowiak, S. Włodyka, Warszawa 2007.

System prawa prywatnego, t. 6, red. A. Olejniczak, Warszawa 2014.

System prawa prywatnego, t. 17B, red. S. Sołtysiński, Warszawa 2010.

Thibaut A., System des Pandekten-Rechts, t. II, Jena 1803.

Węgrzynowski Ł., Charakterystyka praw i obowiq̨zów spótki kapitatowej po jej wykreśleniu z rejestru przedsiębiorców (cz. II), PPH 2014, nr 8.

Zawada K., Umowa przelewu, Kraków 1990.

Zedler F., Dochodzenie roszczeń wierzycieli handlowej spótki kapitatowej po zakończeniu postępowania upadtościowego obejmującego likwidacjejej majątku, [w:] Problemy polskiego i europejskiego prawa prywatnego. Ksiega pamiątkowa Profesora Mariana Kępińskiego, Warszawa 2012. 
306 | Adam Mickiewicz University Law Review

\section{SUMMARY \\ The end of the legal existence of a capital company and the expiration of its debts}

Under Polish law, indebted companies can be liquidated without satisfying all the creditors. Therefore, debts may remain without a debtor. This issue is controversial in the Polish judicature. One way of thinking considers debt to be so closely joined with the debtor that when the debtor's existence ends with no successor, the debts also end their existence. The other opinion holds that debts of the liquidated company do not cease to exist and may be claimed from the guarantor. As a rule, in Polish law debt is not strictly connected to the debtor or creditor and a change of debtor or creditor is possible. An old Ius Commune rule nomina ossibus inhaerent is not recognized in Poland. Thus the opinion that debts do not vanish after the liquidation of a company is more correct from the dogmatic point of view. Such a stance is also supported by a recent change in the Law on National Court Register.

Keywords: Polish commercial law, capital companies' liquidation, liquidated companies' debts in the Polish law, concept of contractual relation in the Polish Supreme Court jurisprudence.

Rafaє Marek, Jagiellonian University, Faculty of Law and Administration, Karola O1szewskiego, 30-962 Kraków, Republic of Poland, e-mail: r.m.a.marek@gmail.com. 